\title{
Stripping off the pericardium: Cures the liver and the kidneys and dries up the ascites
}

\author{
Awad Magbri*, Shaukat Rashid and Balhinder Brar \\ Toledo vascular access center, OH, USA
}

\section{Case history}

A 62 year-old Caucasian male, with past medical history of coronary heart disease, type- 2 diabetes mellitus, obstructive sleep apnea, and hyperlipidemia, admitted to the hospital with an episode of hypoglycemia and unresponsiveness. He was diagnosed in the past by his gastro-enterologist as having "liver disease", the nature of which was not clear. His physical examination showed that he was well nourished man with regular heart rate, no edema or jugular venous distension but his serum creatinine was $1.9 \mathrm{mg} / \mathrm{dl}$ and had un-quantifiable proteinuria in his urine analysis which initiate a nephrology consultation. $\mathrm{He}$ returned to the nephrology clinic after discharge from the hospital on $12 / 15 / 16$ with increasing serum creatinine from 1.9 to $2.5 \mathrm{mg} / \mathrm{dl}$ and an estimated GFR of $30 \mathrm{ml} / \mathrm{min}$. During this encounter he denies any nausea, vomiting, diarrhea, or use of non-steroidal anti-inflammatory medications (NSAID). In the interim, he stated that he had paracentesis of 17 liters on 12/07/16 for his ascites.

On his follow up visit on $1 / 31 / 17$ his examination was unremarkable and his serum creatinine had gone down to $1.9 \mathrm{mg} / \mathrm{dl}$. During this time he was diagnosed with liver cirrhosis but had no liver biopsy or more detailed information about the diagnosis. His hepatitis serology was negative and liver function test were within normal range. He returned to the nephrology clinic on $3 / 8 / 17$ with increasing serum creatinine to $3.82 \mathrm{mg} / \mathrm{dl}$ and blood urea nitrogen (BUN) increasing from 37 to $73 \mathrm{mg} / \mathrm{dl}$. He had a transthoracic echocardiogram which showed left ventricular dysfunction.

The patient returned to the nephrology clinic once again on the $3 / 17 / 17$, with stable serum creatinine of 3.8 and BUN of $79 \mathrm{mg} / \mathrm{dl}$. But this time he had fluid overloaded with increased edema of the lower extremities and tense ascites. He stated that he had been scheduled for paracentesis and cardiac catheterization on 3/29/17.

On the next visit on $4 / 24 / 17$, his eGFR had gone down and was classified to CKD stage-4. During this visit he was diagnosed with chronic constrictive pericarditis (CP) on cardiac catheterization. His edema had been controlled with medications, and paracentesis. $\mathrm{He}$ was scheduled to have pericardiectomy in the following few days. His serum creatinine had gone up to $4.4 \mathrm{mg} / \mathrm{dl}$. He continued to have paracentesis and hemodialysis to control his edema and renal function. His last paracentesis was on 5/8/17 with $10.7 \mathrm{~L}$ removed.

On $5 / 17$ he had surgery on the pericardium with chest tube insertion $x$ 3. During this hospital admission and following surgical procedure his heart function, renal function, and urine output had improved. $\mathrm{He}$ was taken off hemodialysis and his final serum creatinine was $1.53 \mathrm{mg} /$ $\mathrm{dl}$ before discharge. He had a total of 4 cardiac catheterizations and the diagnosis of CP was clenched on the $3^{\text {rd }}$ catheterization. He had multiple paracentesis with total fluid loss of $111 \mathrm{Lb}$. and total fluid removal by paracentesis of $21.6 \mathrm{~L}$.

\section{Discussion of the case}

This case illustrated the importance of vanishing arts of clinical history, examination, and analytical data interpretation. The patient presented with edema, ascites, fluid overload, normal hepatitis serology and liver function, and progressive increase in blood urea nitrogen (BUN) and creatinine. He underwent a total of 4 cardiac catheterization before the final clinical diagnosis is attained. The sensitivity of transthoracic echocardiography (TTE) is not high (40\%) compared with the trans-esophageal (TEE) for the diagnosis of valvular diseases, diseases of the myocardium, and pericardium linings [1].

Serology for hepatitis B and C were negative as other liver function tests. A diagnosis of cirrhosis without liver biopsy was given because of ascites. Considerations of pre-hepatic, hepatic and posthepatic causes of ascites were not analyzed in the context of patient's history and clinical examinations. As a matter of fact very often CP is misdiagnosed as cirrhosis because of hepatomegaly and ascites. On the other hand ultra-sound examination of the abdomen in this case revealed no splenomegaly, evidence of fibrosis, or obstruction to the portal or hepatic veins. I am not sure if portal vein and hepatic venous pressures and their variation with respiration were measured during this encounter. The patient was treated symptomatically with diuretics, paracentesis, and eventually hemodialysis to control ascites, peripheral edema, and deteriorated kidney function.

The case is also unique as it presented with increasing BUN and creatinine in the absence of significant proteinuria, making intrinsic renal disease unlikely. The ultra-sound of the kidneys excluded obstruction of the genitourinary tract making pre-renal diseases with congestive nephropathy a more likely scenario. One wonders why cardiac catheterization were performed in more than 3 occasions to achieve the diagnosis. I do not know whether the intra-cardiac pressures were measured in the first 2 catheterizations or not.

On 5/12/16 both right and left cardiac catheterization was done which showed no coronary artery disease or evidence of CP. His

Correspondence to: Awad Magbri, Toledo vascular access center, OH, USA, E-mail: elmagbri@hotmail.com

Key words: constrictive pericarditis, cirrhosis, cardiac catheterization, ascites, proteinuria, hemodialysis, echocardiography, congestive nephropathy, congestive hepatomegaly

Received: February 03, 2018; Accepted: February 26, 2018; Published: February 28,2018 
transthoracic echocardiogram was also normal with ejection fraction of $60 \%$ which is very commonly encountered in CP.

If we trace his serum creatinine as far back as 1/27/14 and 6/26/15 (1.0 and $0.84 \mathrm{mg} / \mathrm{dl}$, respectively), one would find that his serum creatinine were normal to start with and progressively getting worse up until his recent admission and the time of surgery after which relief of congestion and improvement of kidney function began to appear, (Table 1).

Constrictive pericarditis is a scaring process which causes loss of normal elasticity of the pericardial sac. It is typically chronic disease which impedes cardiac filling by the external forces. In the most severe form of CP the pericardium becomes almost inelastic which compromises volume changes during respiration.

In normal situation the normal pericardium does not interfere with the decrease in intra-thoracic pressure during inspiration which leads to increase in venous return to the right side of the heart. This increase in venous return to the right side of the heart does not impair left ventricular filling.

However, in CP cardiac volume is constrained which prevents normal inspiratory decrease in intra-thoracic pressure from being transmitted to the heart chambers. Pulmonary venous pressure decrease during inspiration, however, left ventricular pressure does not. This divergences will results in decreased left ventricular volume as a results of a decrease in trans-pulmonary gradient. These pathophysiological abnormalities lead to shifting of interventricular septum to the left during expansion of the right ventricle further compromising left ventricular end-diastolic volume. In severe $\mathrm{CP}$ the ventricular filling occurs in early diastole with little or no filling subsequently. As CP becomes more severe the ventricular volumes and stroke volumes are reduced $[2,3]$.

The etiology of $\mathrm{CP}$ are identified in case series reported by previous workers [4-9].

- Idiopathic or viral

- Post-radiation

- Connective tissue disorders

- Post-cardiac surgery

- Post-infectious

- Miscellaneous causes (malignancy, Trauma, drug induced, asbestosis, Sarcoidosis, uremic pericarditis)

up to $10 \%$

Table 1. Time-line for serum creatinine.

\begin{tabular}{|c|c|c|c|c|c|c|c|c|}
\hline Date & $5 / 11 / 16$ & $12 / 25 / 16$ & $1 / 31 / 17$ & $3 / 8 / 17$ & $3 / 17 / 17$ & $4 / 24 / 17$ & $5 / 22 / 17$ & $7 / 8 / 17$ \\
\hline Serum creatinine in $\mathrm{mg} / \mathrm{dl}$ & 1.38 & 2.5 & 1.9 & 3.82 & 3.8 & 4.4 & 2.41 & 1.8 \\
\hline
\end{tabular}

Table 2. Differences between constrictive pericarditis and restrictive cardiomyopathy.

\begin{tabular}{|c|c|c|}
\hline Characteristics & $\mathrm{CP}$ & RCMP \\
\hline $\begin{array}{l}\text { History } \\
\text { - Prior pericarditis } \\
\text { - Cardiac surgery } \\
\text { - Irradiation } \\
\text { - DM, amyloidosis, sarcoidosis }\end{array}$ & $\begin{array}{l}\text { Yes } \\
\text { Yes } \\
\text { Yes } \\
\text { No }\end{array}$ & $\begin{array}{l}\text { No } \\
\text { No } \\
\text { No/Yes } \\
\text { Yes }\end{array}$ \\
\hline $\begin{array}{l}\text { Physical examination } \\
\text { - JVP } \\
\text { - Pericardial knock } \\
\text { - S3 }\end{array}$ & $\begin{array}{l}\text { more common } \\
\text { Yes } \\
\text { No }\end{array}$ & $\begin{array}{l}\text { Yes } \\
\text { No } \\
\text { Yes }\end{array}$ \\
\hline $\begin{array}{l}\text { ECG findings } \\
\text { - BBB } \\
\text { - Ventricular hypertrophy } \\
\text { - Pathological Q wave } \\
\text { - impaired atrio-ventricular conduction }\end{array}$ & $\begin{array}{l}\text { No } \\
\text { No } \\
\text { No } \\
\text { No }\end{array}$ & $\begin{array}{l}\text { Yes } \\
\text { Yes } \\
\text { Yes } \\
\text { Yes }\end{array}$ \\
\hline B-type BNP & Usually in normal range & Usually raised \\
\hline $\begin{array}{l}\text { CXR } \\
\text { - Calcification } \\
\text { - cardiomegaly }\end{array}$ & $\begin{array}{l}\text { Yes } \\
\text { No }\end{array}$ & $\begin{array}{l}\text { No } \\
\text { Yes }\end{array}$ \\
\hline $\begin{array}{l}\text { Imaging (Doppler, echo, CT, CMR) } \\
\text { - increased thickens of pericardium or calcification } \\
\text { - Thick ventricular wall or septum } \\
\text { - MR or TR }\end{array}$ & $\begin{array}{l}\text { Yes } \\
\text { No } \\
\text { No }\end{array}$ & $\begin{array}{l}\text { No } \\
\text { Yes } \\
\text { Yes }\end{array}$ \\
\hline $\begin{array}{l}\text { Doppler } \\
\text { - Respiratory variation in ventricular filling velocity } \\
\text { - Hepatic venous flow reversal } \\
\text { - Diastolic MR }\end{array}$ & $\begin{array}{l}\text { High usually in } 30-40 \% \\
\text { Expiratory } \\
\text { No }\end{array}$ & $\begin{array}{l}\text { Minimal }<10 \% \\
\text { Inspiratory } \\
\text { Yes }\end{array}$ \\
\hline $\begin{array}{l}\text { Tissue Doppler imaging } \\
\text { - Early diastolic Doppler tissue velocity @M annulus (E’) } \\
\text { - Doppler myocardial velocity gradient @ LVW in early } \\
\text { diastole and during ventricular ejection }\end{array}$ & $\begin{array}{l}\text { Increased }>12 \mathrm{~cm} / \mathrm{sec} \\
\text { Comparable to normal }\end{array}$ & $\begin{array}{c}\text { Decreased to }<8 \mathrm{~cm} / \mathrm{sec} \\
\text { Significantly lower }\end{array}$ \\
\hline $\begin{array}{l}\text { Cardiac catheterization } \\
\text { - Right and left ventricular end-diastolic pressure (RVEDP } \\
\text { \& LVEDP) }\end{array}$ & Equal or near equal & LVEDP $>$ RVEDP \\
\hline $\begin{array}{l}\text { Biopsy } \\
\text { - Endomyocardium or less commonly pericardium }\end{array}$ & May be helpful & May be helpful \\
\hline
\end{tabular}


Orthotopic heart transplant and tuberculous pericarditis have been associated with high incidence of CP $(49 \%)$ in developing world $[10,11]$. IgG4 diseases and Whipple's disease have also been incriminated in cases of CP $[12,13]$.

The clinical presentation of CP are protean, and includes volume overload manifested as peripheral edema, ascites and anasraca, low cardiac output with exertional dyspnea, fatigability and signs of heart failure or symptoms of cardiac tamponed.

On physical examination, patients with $\mathrm{CP}$ often exhibit raised jugular venous pressure (JVP), pulsus paradoxus [4,14], Kussmaul's signs [8,9], a pericardial knock [8], edema, ascites, pulsatile liver, and cachexia. JVP is reported in $93 \%$ of cases of CP [8]. Unexplained raised JVP in patients with predisposing conditions like malignancy, irradiation, or pervious cardiac surgery should alert the physician to the presence of CP.

Evaluation of $\mathrm{CP}$ should include chest $\mathrm{x}$-ray which might show calcification. Echocardiography both 2-D and M-mode which can be done as transthoracic or trans-esophageal echocardiography (TTE or TEE). The TEE is more sensitive [1-3,15-20]. CT and cardiac magnetic resonance (CMR) are very sensitive modalities for detection of pericardial thickening and calcification in $\mathrm{CP}[3,15]$ [21-24]. Hemodynamic evaluation during cardiac catheterization are sometimes needed to confirm the diagnosis of CP $[2,3,15,25]$.

Plasma BNP are elevated in cardiomyopathy and left ventricular dysfunction but less so in CP. The differential diagnoses of CP includes cardiac tamponade, restrictive cardiomyopathy, and cirrhosis. Table 2 showed the difference between $\mathrm{CP}$ and restrictive cardiomyopathy.

Acute kidney injury (AKI) is rare manifestation of CP. The pathophysiology is probably linked to congestive nephropathy with high renal vein pressure and little in the way of proteinuria as illustrated in this case. The high pressures in the renal veins are transmitted back to the glomeruli with decrease in the glomerular filtration rate. Once the pressure is relieved by pericardiectomy the renal function usually reverted to normal.

The treatment of CP is pericardiectomy [26-29]. Striping of as much as possible of the pericardium is advisable to have the gratifying effects of surgery especially if surgery is carried out early in the disease process. In many instants relief of ascites, peripheral edema and congestive hepatopathy and nephropathy would ensue more quickly.

The take home message in this case is never abandoned good clinical history, physical examination looking for signs of $\mathrm{CP}$ especially raised JVP, pulsatile liver, and ascites. The art of history taking and physical examination together with analytical interpretation of the data will sharpen our clinical acumen and in most cases would lead you to the correct diagnosis.

\section{References}

1. Agatston AS, Rao A, Price RJ, Kinney EL (1978) Diagnosis of constrictive pericarditis by pulsed Doppler echocardiography. Am J Cardiol 42: 388.

2. Troughton RW, Asher CR, Klein AL (2004) Pericarditis. Lancet 363: 717. [Crossref]

3. Adler Y, Charron P, Imazio M, Badano L, Barón-Esquivias G, et al. (2015) 2015 ESC Guidelines for the diagnosis and management of pericardial diseases: The Task Force for the diagnosis and management of pericardial diseases of the European Society of Cardiology (ESC) Endorsed by: The European Association of Cardio-Thoracic Surgery (EACTS). Eur Heart J 36: 2921. [Crossref]

4. Vistarini N, Chen C, Mazine A, Bouchard D, Hebert Y et al. (2015) Pericardiectomy for constrictive pericarditis: 20 years of experience at the Montreal Heart Institute. Ann Thorac Surg 100: 107. [Crossref]
5. George TJ, Arnaoutakis GJ, Beaty CA, kilic A, Baumgartner WA, et al. (2012) Contemporary etiologies, risk factors, and outcomes after pericardiectomy. Ann Thorac Surg 94: 445. [Crossref]

6. Szabo G, Schmack B, Bulut C, Soós P, Weymann A, et al. (2013) Constrictive pericarditis: risks, etiologies, and outcomes after total pericardiectomy: 24-years' experience. Eur J Cardiothorac Surg 44: 1023. [Crossref]

7. Bertog SC, Thambidorai SK, Parakh K, Schoenhagen P, Ozduran V, et al. (2004) Constrictive pericarditis: etiology and cause-specific survival after pericardiectomy. $J$ Am Coll Cardiol 43: 1445. [Crossref]

8. Ling LH, Oh JK, Schaff HV, Danielson GK, Mahoney DW, et al. (1999) Constrictive pericarditis in the modern era: evolving clinical spectrum and impact on outcome after pericardiectomy. Circulation 100: 1380. [Crossref]

9. Cameron J, Oesterle SN, Baldwin JC, Hancock EW (1987) The etiologic spectrum of constrictive pericarditis. Am Heart J 113: 354. [Crossref]

10. Bansal R, Perez L, Razzouk A, Wang N, Bailey L, et al. (2010) Pericardial constriction after cardiac transplantation. J Heart Lung Transplant 29: 371. [Crossref]

11. Robertson R, Arnold CR (1962) Constrictive pericarditis with particular reference to etiology. Circulation 26: 525. [Crossref]

12. Sekiguchi H, Horie R, Suri RM, Yi ES, Ryu JH, et al. (2012) Constrictive pericarditis caused by immunoglobulin G4-related disease. Circ Heart Fail 5: e30. [Crossref]

13. Stojan G, Melia MT, Khandhar SJ, Illei P, Baer AN et al. (2013) Constrictive pleuropericarditis: a dominant clinical manifestation in Whipple's disease. BMC Infect Dis 13: 579. [Crossref]

14. Spodick DH (1983) The normal and diseased pericardium: current concepts of pericardial physiology, diagnosis and treatment. J AM Coll Cardiol 1: 240. [Crossref]

15. Talreja DR, Edwards WD, Danielson GK, Schaff HV, Tajik AJ, et al. (2003) Constrictive pericarditis in 26 patients with histologically normal pericardial thickness. Circulation 108: 1852 .

16. Schnittger I, Bowden RE, Abrams J, Popp RL (1978) Echocardiography: pericardial thickening and constrictive pericarditis. Am J Cardiol 42: 388. [Crossref]

17. Agatston AS, Rao A, Price RJ, Kinney EL (1984) Diagnosis of constrictive pericarditis by pulsed Doppler echocardiography. Am J Cardiol 54: 929. [Crossref]

18. Cheitlin MD, Armstron WF, Aurigemma GP, Beller GA, Bierman FZ, et al. (2003) ACC/AHA 2003 guideline update for the clinical application of echocardiography: summery article: a reportof the American College of Cardiology/American Heart Asscociation Task Force on Practice Guidelines (ACC/AHA/ASE Committee to Update the 1997 Guidelines for the clinical application of echocardiography). J Am Soc Echocardiogr 16: 1091. [Crossref]

19. Hoit BD (1990) Imaging the pericardium. Clin Cardiol 8: 587.

20. D’Cruz IA, Dick A, Gross CM, Hand CR, Lalmalani GG, et al. (1989) Abnormal left ventricular-left atrial posterior wall contour: a new two-dimensional echocardiographic sign in constrictive pericarditis. Am Heart J 118: 128. [Crossref]

21. Verhaert D, Gabriel RS, Johnston D, Lytle BW, Desai MY, et al. (2010) The role of multimodality imaging in the management of pericardial disease. Cir Cardiovasc Imaging 3: 333. [Crossref]

22. Breen JF (2001) Imaging of the pericardium. J Thorac Imaging 16: 47.

23. Kojima S, Yamada N, Goto Y (1999) Diagnosis of constrictive pericarditis by tagged cine magnetic resonance imaging. N Engl J Med 341: 373. [Crossref]

24. Masui T, Finck S, Higgins CB (1992) Constrictive pericarditis and restrictive cardiomyopathy: evaluation with MR imaging. Radiology 182: 369. [Crossref]

25. Hurrell DG, Nishimura RA, Higano ST, Appleton CP, Danielson GK, et al. (1996) Value of dynamic respiratory changes in left and right ventricular pressures for the diagnosis of constrictive pericarditis. Circulation 93: 2007. [Crossref]

26. Chowdhury UK, Subramaniam GK, Kumar AS, Airan B, Singh R, et al. (2006) Pericardiectomy for constrictive pericarditis: a clinical, echocardiographic, and hemodynamic evaluation of two surgical techniques. Ann Thorac Surg 81: 522. [Crossref]

27. DeValeria PA, Baumgartner WA, Casale AS, Greene PS, Cameron DE, et al. (1991) Current indications, risks, and outcome after pericardiectomy. Ann Thorac Surg 52 219. [Crossref] 
Magbri A (2018) Stripping off the pericardium: Cures the liver and the kidneys and dries up the ascites

28. Murashita T, Schaff HV, Daly RC, Oh JK, Dearani JA et al. (2017) Experience with pericardiectomy for constrictive pericarditis over eight decades. Ann Thorac Surg 104: 742. [Crossref]
29. Ha JW, Oh JK, Schaff HV, Ling LH, Higano ST, et al. (2008) Impact of left ventricular function on immediate and long-term outcomes after pericardiectomy in constrictive pericarditis. J Thorac Surg 136: 1136. [Crossref]

Copyright: (C2018 Magbri A. This is an open-access article distributed under the terms of the Creative Commons Attribution License, which permits unrestricted use, distribution, and reproduction in any medium, provided the original author and source are credited. 